\title{
A new species of rust fungi from the middle Eocene Sakhalinian amber
}

Yuri Tykhonenko, Vera Hayova, Mikhail Ignatov, Dmitry Vasilenko, and Evgeny E. Perkovsky Acta Palaeontologica Polonica 66 (4), 2021: 921-924 doi:https://doi.org/10.4202/app.00917.2021

Nyssopsora eocaenica Tykhonenko and Hayova sp. nov., the only fossil species of the genus Nyssopsora (Pucciniales), is described from the middle Eocene Sakhalinian amber (Russian Far East). It differs from the other known representatives of the genus by the presence of unbranched hooked appendages on the surface of teliospores. The spores are embedded in the amber sample in close proximity to a syninclusion, Heterotrissocladius naibuchi (Diptera, Chironomidae); most of them are clinged to the insect's wing or entangled in the bristles on its legs and body. This fossil is ca. 45 myr old and provides useful information for future phylogeny-based calibration and dating of the rust fungi.

Yuri Tykhonenko [yu.ya.tykhonenko@gmail.com; ORCID: https://orcid.org/0000-0001-9000-7406] and Vera Hayova [v.hayova@gmail.com, https://orcid. org/0000-0002-7038-1633] (corresponding author); Kholodny Institute of Botany, National Academy of Sciences of Ukraine, 2 Tereshchenkivska Str., Kyiv, 01601, Ukraine. Mikhail Ignatov [misha ignatov@list.ru ; ORCID: https://orcid.org/0000-0001-6096-6315], Tsytsin Main Moscow Botanical Garden of Academy of Sciences, Russian Academy of Sciences, 4 Botanicheskaya Str., Moscow,127276, Russia. Dmitry Vasilenko [damageplant@mail.ru ], Borissiak Paleontological Institute, Russian Academy of Sciences, 123 Profsoyuznaya Str, Moscow, 117647, Russia and Cherepovets State University, Lunacharsky Avenue, 5, Cherepovets, 162600, Russia. Evgeny E. Perkovsky [perkovsk@ gmail.com; ORCID: https://orcid.org/0000-0002-7959-4379], Schmalhausen Institute of Zoology, National Academy of Sciences of Ukraine, 15 Bogdan Khmelnitski Str., Kyiv, 01601, Ukraine.

This is an open-access article distributed under the terms of the Creative Commons Attribution License (for details please see creativecommons.org), which permits unrestricted use, distribution, and reproduction in any medium, provided the original author and source are credited. 
Fof Full text $(652.2 \mathrm{kB})$ 